\title{
Modification of Functional Polyesters Bearing Norbornene Moieties via Olefin Metathesis Reactions
}

\section{Olefin Metatez Tepkimeleri ile Norbornen İçeren Fonksiyonel Poliesterlerin Modifikasyonu}

\author{
Research Article \\ Bengi Özgün Öztürk* \\ Department of Chemistry, Faculty of Science, Hacettepe University, Ankara, Turkey.
}

\section{A B S TR ACT}

\begin{abstract}
n this study, unsaturated functional polyester derivatives were synthesized via polycondensation reactions of 5-norbornene-2,3-dicarboxylic anhydride and 1,6-hexanediol. Functional unsaturated polyesters were modified using methyl acrylate as ring opening/cross-metathesis reaction partner. The solubility and hydrophobic/hydrophilic character of polyester was tuned by integrating allyl end capped poly(ethyleneglycol) by ring opening/cross-metathesis reactions. Norbornene moiety of unsaturated polyesters allowed us to use ring opening metathesis polymerization reactions to form side-chain poly(norbornene) on main polyester chain using Grubbs $1^{\text {st }}, 3^{\text {rd }}$ and Hoveyda-Grubbs $2^{\text {nd }}$ generation catalysts as initiators, resulting in gel-like materials.
\end{abstract}

\section{Key Words}

Ring opening/cross-metathesis, polyesters, ruthenium, polycondensation.

\section{öz}

u çalışmada doymamış fonksiyonel poliester türevleri 5-norbornen-2,3-dikarboksilik anhidrit ve 1,6-hekzandiol bileşiklerinin polikondenzasyon tepkimeleri ile elde edilmiştir. Fonksiyonel doymamış poliesterler metil akrilat kullanılarak halka açılma/çapraz metatez tepkimeleri ile modifiye edilmiştir. Poliesterlerin çözünürlük ve hidrofobik/hidrofilik karakterleri halka açılma/çapraz metatez tepkimeleri ile alil son grubuna sahip poli(etilenglikol) bileşikleri entegre edilerek değiştirilmiştir. Doymamış poliesterlerdeki norbornen grubu sayesinde jel benzeri malzemeler, Grubbs birinci, üçüncü ve Hoveyda-Grubbs ikinci nesil katalizörleri varlığında halka açılım metatez polimerizasyon tepkimeleri ile ana poliester zinciri üzerinde yan poli(norbornen) zincirlerinin oluşumu ile elde edilmiştir.

\section{Anahtar Kelimeler}

Halka açılım/çapraz metatez, poliester, rutenyum, polikondenzasyon.

Article History: Received: Jun 02, 2017; Revised: Aug 12, 2017; Accepted: Oct 18, 2017; Available Online: Feb 20, 2018.

DOI: $10.15671 /$ HJBC.2018.215

Correspondence to: B.Ö. Öztürk, Department of Chemistry, Faculty of Science, Hacettepe University, Ankara, Turkey. 


\section{INTRODUCTION}

Trin he functionalization of synthetic polymers is in great importance owing to their application fields such as smart materials design, drugdelivery, biomaterials and gene-therapy [14]. In order to adapt polyester derivatives to above mentioned applications polymers should have amorphous, water-soluble and must have reactive groups to functionalize polymer chain [5]. The traditional polymers such as poly(Llactic acid) (PLLA) poly(glyclolic acid) (PGA), poly(caprolactone) (PCL) are synthesized by ringopening polymerization (ROP), mostly yielding hydrophobic and semi-crystalline polymers [6]. For the past decade, several studies are focused on the synthesis of amorphous aliphatic polyesters that can be used in several fields [7]. The integration of functional polar group on polymer chain is used as an efficient strategy. Amsden and research group have reported acrylate terminated star shaped polymers bearing amorphous poly(DL-lactic acid) (PDLLA) [8]. The cross-linking ability of the material was investigated by varying the length of the arms of the stars and photo-curing conditions. Sebacic acid and glycerol was used by Langer et. al for the synthesis of a though biodegradable elastomer, exhibiting total amorphous property at $37^{\circ} \mathrm{C}$ [9]. In 2007 Sheares et. al. have used linear diols and dicarboxylic monomers to obtain unsaturated aliphatic polyesters via step growth polycondensation [10]. In addition to anhydridediol combination, epoxy based materials were also polymerized with anhydride based monomers [11]. Unsaturated polyesters are in great importance in polymer chemistry since they can be used to synthesize functional materials by modification through double bonds [12]. Cross-metathesis is a valuable partner for modification of unsaturated polymers [13-14] $\beta$-heptenolactone $(\beta \mathrm{HL})$ based polyesters were modified via olefin cross-metathesis reactions altering the thermal, chemical and physical properties of polymers [15]. In addition to repeating unit modification reactions, cross-metathesis reactions are also used for end-capping of polymers [16]. Recently, greener approaches have been developed for polyester synthesis utilizing furfural [17] and epoxides [18].
Here in, we report an efficient method for postmodification of unsaturated polyester derivatives via ring opening/cross-metathesis and ring opening metathesis polymerization. The effect of crossmetathesis modification on $T_{g}$ and solubility of the polymer was investigated in details. Thermoplastics with relatively higher thermal stabilities were obtained by ROMP of norbornene moiety of unsaturated polyesters in the presence of Grubbs $1^{\text {st }}, 3^{\text {rd }}$ and Hoveyda-Grubbs $2^{\text {nd }}$ generation catalysts.

\section{MATERIALS and METHODS}

\section{Chemicals and Instruments}

Otherwise noted all chemicals were purchased from Sigma-Aldrich and used as received. Umicore@M1 was purchased from Strem Chemical Inc. ${ }^{1} \mathrm{H}$ and ${ }^{13} \mathrm{C}$ nuclear magnetic resonance (NMR) spectra were recorded at $25^{\circ} \mathrm{C}$ with a Bruker $\mathrm{GmbH} 400 \mathrm{MHz}$ high-performance digital FTNMR spectrometer using $\mathrm{CDCl}_{3}$ as the solvent. Molecular weights were determined with a GPC System LC-20A from Shimadzu equipped with SIL-20A autosampler, RID-10A, and a refractive index detector. The analysis was performed on the following column system operating on THF (flow rate $1 \mathrm{~mL} \mathrm{~min}^{-1}$ ) at $40^{\circ} \mathrm{C}$ : main-column PSS SDV analytical $(5 \mu \mathrm{m}, 300 \mathrm{~mm} \times 8.0 \mathrm{~mm}, 10000$ $\AA)$ and a PSS SDV analytical precolumn $(5 \mu \mathrm{m}$, $50 \mathrm{~mm} \times 8.0 \mathrm{~mm}$ ). The calibration was created using narrow linear poly(methyl methacrylate) standards (Polymer Standards Service PPS, Germany) ranging from 1100 to $981000 \mathrm{Da}$.

\section{Synthesis of $\mathbf{P 1}$}

A Schlenk reactor was charged with 5-norbornene-2,3-dicarboxylic anhydride $(1.0 \mathrm{~g}, 6.10 \mathrm{mmol})$ and 1,6-hexanediol $(7.30 \mathrm{mmol}, 0.865 \mathrm{~g})$. The reaction mixture was taken to a pre-heated oil bath $\left(120^{\circ} \mathrm{C}\right)$ and stirred for $10 \mathrm{~min}$ prior to addition of catalyst; $\mathrm{Sn}(\mathrm{Oct})_{2}(0.061 \mathrm{mmol})$. After addition of catalyst to the reactor, Schlenk reactor was connected to a vacuum pump (vacuum value; 30-40 torr) and reaction mixture was stirred for $12 \mathrm{~h}$ under these conditions. After $12 \mathrm{~h}$, reaction mixture was cooled down and poured into cold-methanol and stirred for additional $30 \mathrm{~min}$. P1 was isolated by simple filtration, followed by washing with cold methanol/acetone mixture. P1 was characterized by ${ }^{1} \mathrm{H},{ }^{13} \mathrm{C}$ NMR and GPC. 
${ }^{1} \mathrm{H}$ NMR $\left(400 \mathrm{MHz}_{1} \mathrm{CDCl}_{3}\right) \delta 6.17(\mathrm{~m}, 2 \mathrm{H}), 4.31-$ $3.79(\mathrm{~m}, 24 \mathrm{H}), 3.43(\mathrm{~d}, \mathrm{~J}=18.2 \mathrm{~Hz}, 2 \mathrm{H}), 3.33-2.95$ $(\mathrm{m}, 2 \mathrm{H}), 1.55-1.29(\mathrm{~m}, 10 \mathrm{H})$.

${ }^{13} \mathrm{C} \mathrm{NMR}\left(101 \mathrm{MHz} \mathrm{CDCl}_{3}\right) \delta 175.23-170.19(\mathrm{~m})$, $137.78(\mathrm{~d}, \mathrm{~J}=30.8 \mathrm{~Hz}), 134.92(\mathrm{~d}, \mathrm{~J}=16.4 \mathrm{~Hz}), 66.15$ - $61.50(\mathrm{~m}), 49.86(\mathrm{~d}, \mathrm{~J}=140.0 \mathrm{~Hz}), 51.81-43.47(\mathrm{~m})$, $32.13-27.77(\mathrm{~m}), 26.49-22.44(\mathrm{~m})$.

\section{Cross-Metathesis Reactions of P1}

A Schlenk reactor was charged with $\mathrm{P} 1\left(0.10 \mathrm{~g}, \mathrm{M}_{\mathrm{n}}\right.$ : $4000 \mathrm{Da})$ in toluene $(5 \mathrm{ml})$. The reactor was taken to a pre-heated oil bath at $85^{\circ} \mathrm{C}$ and stirred for 10 min prior to addition of Hoveyda-Grubbs $2^{\text {nd }}$ generation catalyst (commercial code C711, $0.01 \mathrm{~g}$, $0.014 \mathrm{mmol}$ ). After addition of the catalyst, reaction mixture was stirred for $12 \mathrm{~h}$ at $85^{\circ} \mathrm{C}$. The reaction was terminated by addition of excess ethyl vinyl ether (2 ml). Resulting polymer (P2) was precipitated in cold methanol and filtrated. Same reactions were also applied for PEG modification of $\mathrm{P} 1$, resulting in $\mathrm{P} 3$.

\section{Ring Opening Metathesis Polymerization of P1}

A Schlenk reactor was charged with $P 1\left(0.10 \mathrm{~g}, \mathrm{M}_{\mathrm{n}}\right.$ : $4000 \mathrm{Da})$ in $\mathrm{CH}_{2} \mathrm{Cl}_{2}(1 \mathrm{ml})$. Grubbs $3^{\text {rd }}$ generation catalyst $(0.01 \mathrm{~g}, 0.011 \mathrm{mmol})$ dissolved in $\mathrm{CH}_{2} \mathrm{Cl}_{2}(1$ $\mathrm{ml}$ ) was added to the reaction mixture. Gelation occurred within 1-2 hours. Reaction mixture was kept under same conditions for $24 \mathrm{~h}$ to make sure for the termination of gelation reaction.

\section{RESULTS and DISCUSSION}

Optimum reaction conditions were investigated for the polymerization of 5-norbornene-2,3-dicarboxylate, 5-norbornene-2,3-dicarboxylate, 5-norbornene-2,3-dicarboxylic acid with 1,6-hexanediol in the presence of tin(II) ethylhexanoate, titanium (IV) isopropoxide and 1,5,7-triazabicyclodecene (TBD) (Scheme 1).
The optimal polymerization reaction found to proceed at $120^{\circ} \mathrm{C}$ with a catalytic loading of $1 \%$ $\mathrm{Sn}(\mathrm{Oct})_{2}$ at reduced pressure (40 Torr) for $24 \mathrm{~h}$. The results were listed in Table 1 . Polyesters with varying $M_{n}$ values between 2000-11000 Da. All polymers are at viscously oil form at room temperature. ${ }^{1} \mathrm{H}$ NMR spectrum of $\mathrm{P} 1$ can be seen in Figure 1. Olefinic proton signals of norbornene ring appeared at 6.17 ppm. $-\mathrm{CH}_{2} \mathrm{COO}$ - group of aliphatic fragment was observed at 3.86-4.00 ppmas multiplets. Other norbornene protons were observed between 3.40-3.09 and 1.29-.1.54 ppm. Aliphatic fragment of polymer showed signals at 1.29-1.54 ppm. ${ }^{13} \mathrm{C}$ NMR spectrum of P1 showed a singlet peak at $172.50 \mathrm{ppm}$ indicating the presence of $-\mathrm{C}=\mathrm{O}$ group. Olefinic carbon signals appeared at $134.90 \mathrm{ppm}$ (Figure 2). A second olefinic peak appeared at $137.78 \mathrm{ppm}$, which belongs to the norbornene unit of polymer chain endgroup. $-\mathrm{OCH}_{2}$ signal was appeared at 64.29 ppm, Differential Scanning Calorimetry (DSC) analysis of P1 showed a glass-transition temperature $\left(T_{q}\right)$ at $-19.70^{\circ} \mathrm{C}$. The olefinic moiety of polyester chains allows one to modify polymer via olefin metathesis reactions. The integration of several functional groups to polymer chains extend the applications of these polyester based materials. P1 was modified using cross-metathesis reactions. Olefinic norbornene moiety of P1 was reacted with methylacrylate and allyl poly(ethyleneglycol); allyl-PEG. Grubbs $1^{\text {st }}$ generation (G1), Grubbs $2^{\text {nd }}$ generation (G2), Grubbs $3^{\text {rd }}$ generation (G3) and Hoveyda-Grubbs $2^{\text {nd }}$ generation (HG2) catalysts were used in olefin metathesis reactions of $\mathrm{P} 1$. In order to optimize the reaction conditions; several reaction parameters such as; temperature, catalytic loading \%, olefin/polyester ratio and solvent effect were investigated in details.

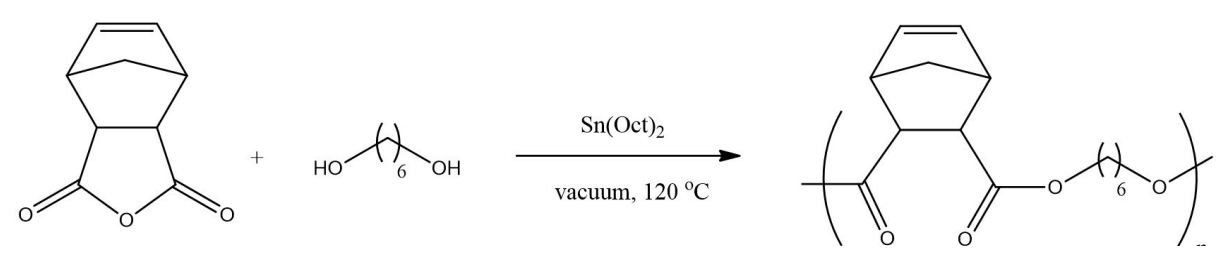

Scheme 1. Polycondensation reactions. 
Table 1. Polycondensation reactions (P1).

\begin{tabular}{cccccc}
\hline Entry & Catalyst & Catalyst $(\%)$ & $\mathrm{M}_{\mathrm{n}}(\mathrm{GPC})(\mathrm{Da})^{\mathrm{a}}$ & $\mathrm{PDI}^{\mathrm{a}}$ & Yield $(\%)^{(}$ \\
\hline 1 & $\mathrm{TBD}$ & 0.5 & 11200 & 2.4 & 80 \\
\hline 2 & $\mathrm{TBD}$ & 1 & 6000 & 2.1 & 90 \\
\hline 3 & $\mathrm{TBD}$ & 2 & 4000 & 2.0 & 85 \\
\hline 4 & $\mathrm{Sn}(\mathrm{Oct})_{2}$ & 0.5 & 8700 & 2.2 & 90 \\
\hline 5 & $\mathrm{Sn}\left(\mathrm{O}_{\mathrm{c}} \mathrm{t}\right) 2$ & 5500 & 2.1 & 94 \\
\hline 6 & $\mathrm{Sn}(\mathrm{Oct})_{2}$ & 2 & 4100 & 1.9 & 75 \\
\hline 7 & $\mathrm{Ti}(\mathrm{O}-\mathrm{i}-\mathrm{Pr})_{4}$ & 0.5 & 8200 & 2.2 & 85 \\
\hline 8 & $\mathrm{Ti}(\mathrm{O}-\mathrm{i}-\mathrm{Pr})_{4}$ & 1 & 6100 & 2.1 & 88 \\
\hline
\end{tabular}

a: Determined by GPC analysis in THF $(1.0 \mathrm{ml} / \mathrm{min})$ against lineer poly(methylmethylacrylate) standarts.

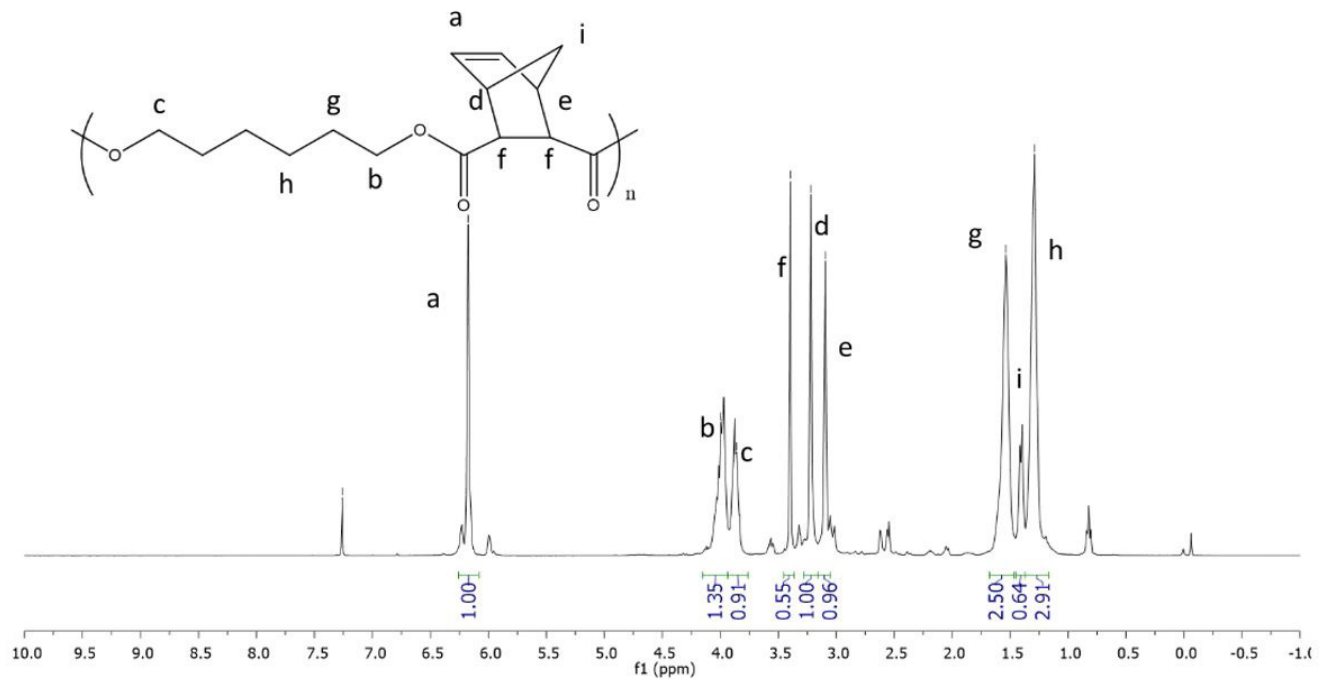

Figure 1. ${ }^{1} \mathrm{H}$ NMR spectrum of $\mathrm{P} 1$.
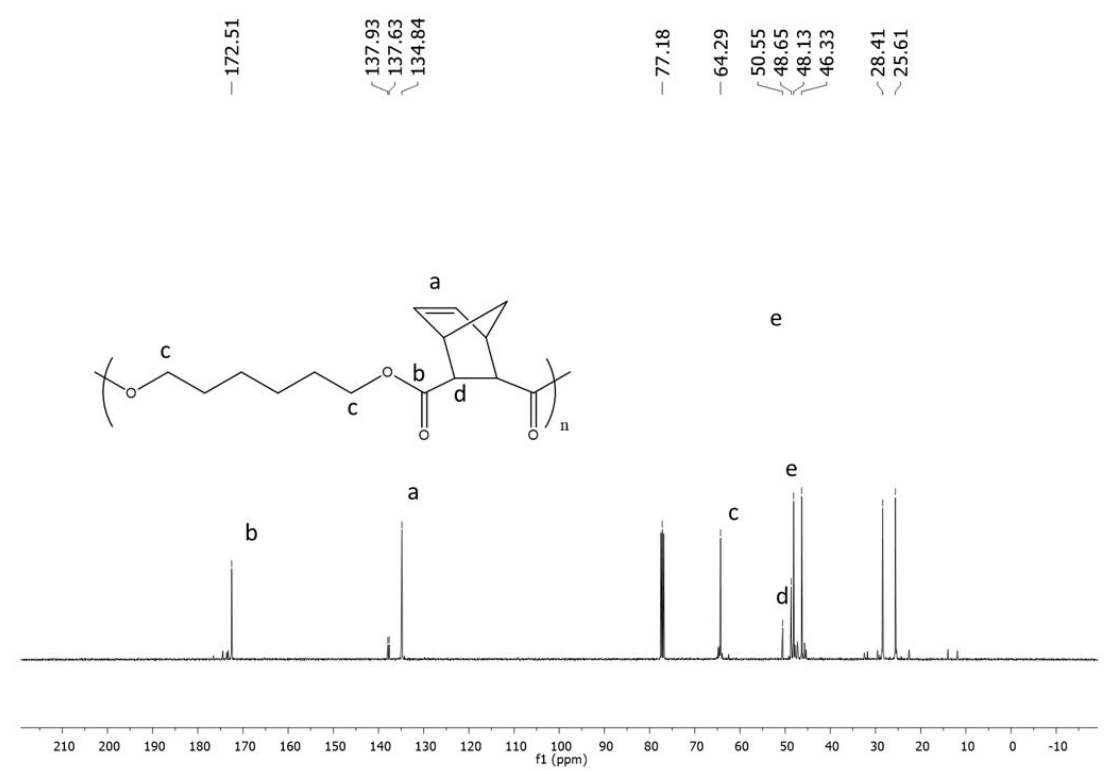

Figure 2. ${ }^{13} \mathrm{C}$ NMR spectrum of $\mathrm{P} 2$. 
The olefinic moiety of polyester chains allows one to modify polymer via olefin metathesis reactions. The integration of several functional groups to polymer chains extend the applications of these polyester based materials. P1 was modified using cross-metathesis reactions. Olefinic norbornene moiety of $\mathrm{P} 1$ was reacted with methylacrylate and allyl poly(ethyleneglycol); allyl-PEG. Grubbs $1^{\text {st }}$ generation (G1), Grubbs $2^{\text {nd }}$ generation (G2), Grubbs $3^{\text {rd }}$ generation (G3) and Hoveyda-Grubbs $2^{\text {nd }}$ generation (HG2) catalysts were used in olefin metathesis reactions of $\mathrm{P} 1$. A set of terminal olefins, methyl acrylate, methyl end capped poly(ethylene glycol) Mn: $500 \mathrm{Da}$ ), allyl bromide and acrylic acid was chosen for ringopening cross metathesis (ROM-CM) reactions. Well-known ruthenium metathesis initiators; Grubbs $1^{\text {st }}(G 1), 2^{\text {nd }}(G 2)$ and $3^{\text {rd }}(G 3)$ and Hoveyda-Grubbs $2^{\text {nd }}$ generation (HG2) complexes were employed in order to find the best performing catalyst. First model reaction was carried out using methyl acrylate as cross-metathesis partner and $\mathrm{P} 1$ in toluene at $80^{\circ} \mathrm{C}$ in the presence of $1 \% \mathrm{G} 1, \mathrm{G} 2, \mathrm{G} 3$ or HG2 (Scheme 2).

The catalysts were compared in means of thermal stability, robustness and activity. Among the tested catalysts HG2 was chosen as best catalyst in means of conversion, selectivity and stability. After $24 \mathrm{~h}$ of intense stirring at $80^{\circ} \mathrm{C}$, reaction was terminated by addition of excess ethyl vinyl ether to reaction media and stirred for an additional 30 min. Polymer was precipitated in cold-methanol. Isolated polymer was labelled as P2. The conversion was determined by ${ }^{1} \mathrm{H}$ NMR by evaluating olefinic proton signals of norbornene and the side-groups of resulting cyclopentane ring. As it can be concluded from ${ }^{1} \mathrm{H}$ NMR spectrum, $\mathrm{ROM}-\mathrm{CM}$ reaction of $\mathrm{P} 1$ with methyl acrylate proceeded with di-substitution of cyclopentane ring (Figure 3) with full conversion.
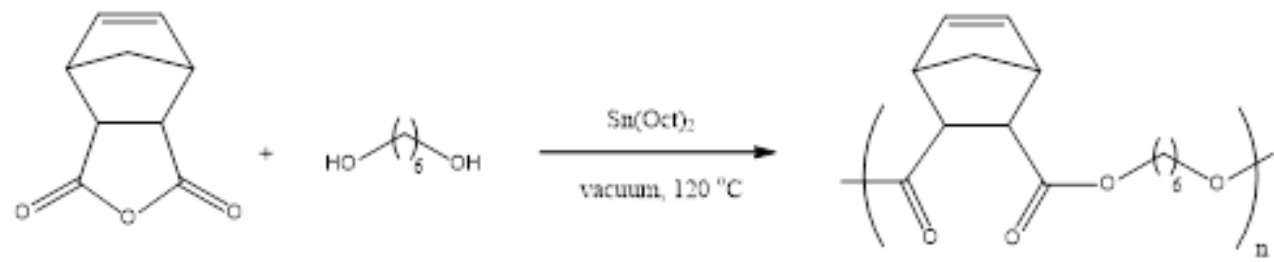

Scheme 2. Synthesis of P2.

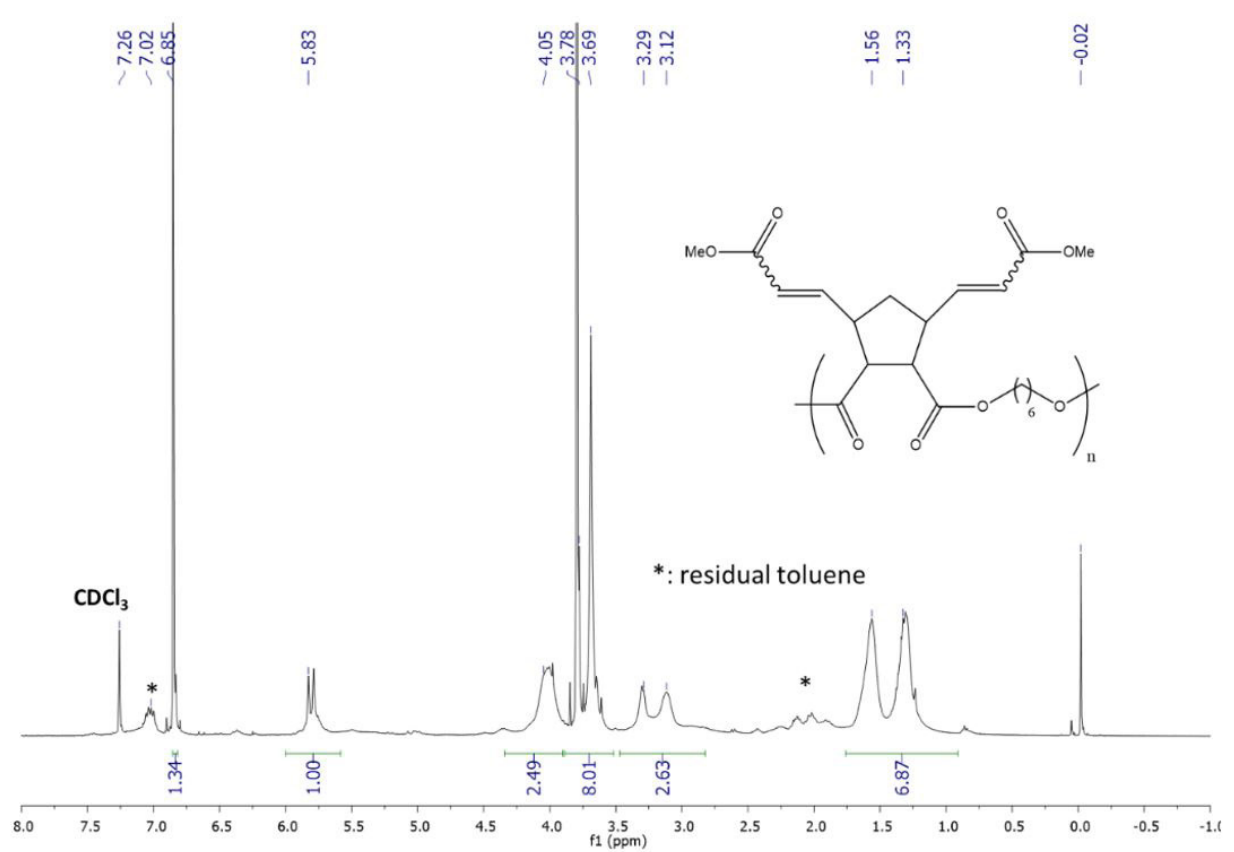

Figure 3. ${ }^{1} \mathrm{H}$ NMR spectrum of $\mathrm{P} 2$. 
Olefinic proton signals were observed at 6.85 $(2 \mathrm{H}, \mathrm{d}, \mathrm{J}=)$ and $5.83(2 \mathrm{H}, \mathrm{d}, \mathrm{J}=) \mathrm{ppm}$, indicating predominant trans-configuration. $-\mathrm{OCH}_{2}-$ group appeared at $4.05 \mathrm{ppm}(4 \mathrm{H}$, as multiplet) and 3.78 ppm. $-\mathrm{OCH}_{3}$ group was observed at $3.69 \mathrm{ppm}$. Although promising results were obtained with methyl acrylate, modification of P1 with other olefins; allyl bromide and acrylic acid were failed due to catalyst decomposition. All catalysts; G1, G2, $\mathrm{G} 3$ and HG2 were poisoned in the presence of these olefinic materials. In the search for water soluble polyester derivatives, we used methyl end capped allyl-PEG (500 Da) for modification of P1 via ROM$\mathrm{CM}$ (Scheme 3). The reaction was carried out at predetermined optimum reaction conditions that for $\mathrm{P} 2$. Once the reaction is completed, P3 was isolated by pouring the reaction mixture to diethyl ether and stored at $-24^{\circ} \mathrm{C}$ overnight for precipitation.

${ }^{1} \mathrm{H}$ NMR results showed that norbornene moiety underwent ROM-CM reactions to form vinyl substituted cyclopentane ring (Figure 4). Vinylic double bond proton peaks appeared at 5.01-5.12 ppm as multiplets, hydrogen atoms bonded to PEG substituted vinyl group appeared at 6.05-5.71 ppm. Hydrogens, the vinyl neighbouring ones, were appeared at $3.85 \mathrm{ppm}$. The repeating group of PEG $\left(-\mathrm{OCH}_{2} \mathrm{CH}_{2}-\right)$ were appeared at $3.47 \mathrm{ppm}$ as a very intense peak. $-\mathrm{OCH}_{2}$ group of polyester chain was observed at $3.20 \mathrm{ppm}$.

The solubility of P1, P2 and P3 was compared in Table 2. As it can be seen in Table 2, P1 and

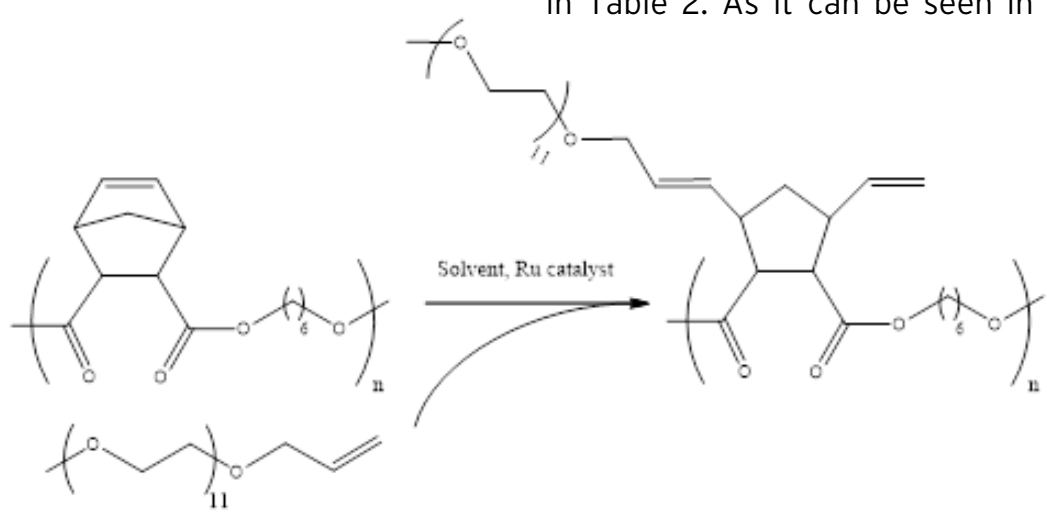

Scheme 3. Synthesis of P3.

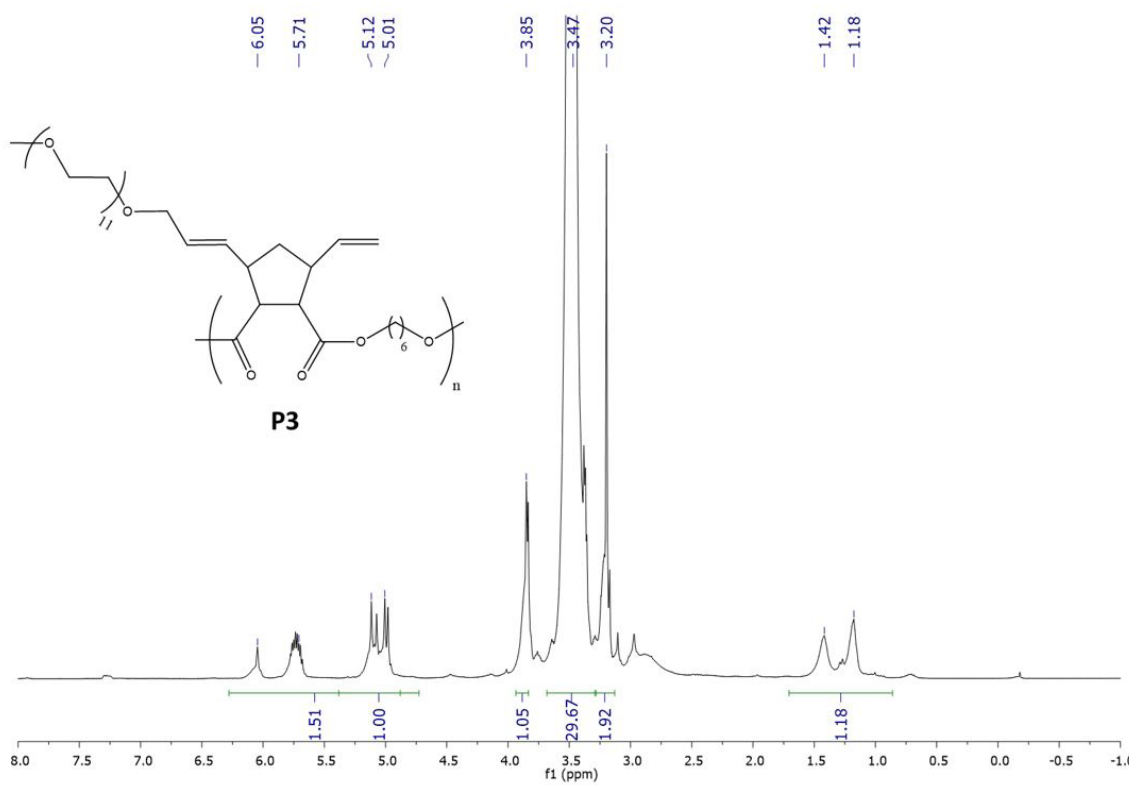

Figure 4. ${ }^{1} \mathrm{H}$ NMR of $\mathrm{P} 3$. 
$\mathrm{P} 2$ is readily soluble in common organic solvents

Following the modification P1 with allyl PEG such as toluene, tetrahydrofuran, dichloromethane, group (P3), the glass transition temperature $\left(\mathrm{T}_{\mathrm{q}}\right)$ chloroform and slightly soluble in acetone and was reduced from $-13.20^{\circ} \mathrm{C}$ to $-19.70^{\circ} \mathrm{C}$ due to the insoluble in hexane and water. P3 is soluble in water contribution of PEG group on overall conformational and common organic solvent; dichloromethane, flexibility of polymer structure.

chloroform, toluene, THF and insoluble in n-hexane.

Table 2. Solubility of polyesters (P1, P2 and P3).

\begin{tabular}{|c|c|c|c|c|c|c|c|c|}
\hline Entry $^{a}$ & $\mathrm{CH}_{3} \mathrm{OH}$ & $\mathrm{CHCl}_{3}$ & $\mathrm{CH}_{2} \mathrm{Cl}_{2}$ & Acetone & Toluene & $\mathrm{H}_{2} \mathrm{O}$ & THF & Hexane \\
\hline P1 & - & + & + & $=$ & + & - & + & - \\
\hline $\mathrm{P} 2$ & - & + & + & $=$ & + & - & + & - \\
\hline P3 & + & + & + & $=$ & + & + & + & - \\
\hline
\end{tabular}

a: -: non-soluble, =: partially soluble, + : soluble.

Table 3. Thermal stability of $\mathrm{P} 1$ after cross-linking.

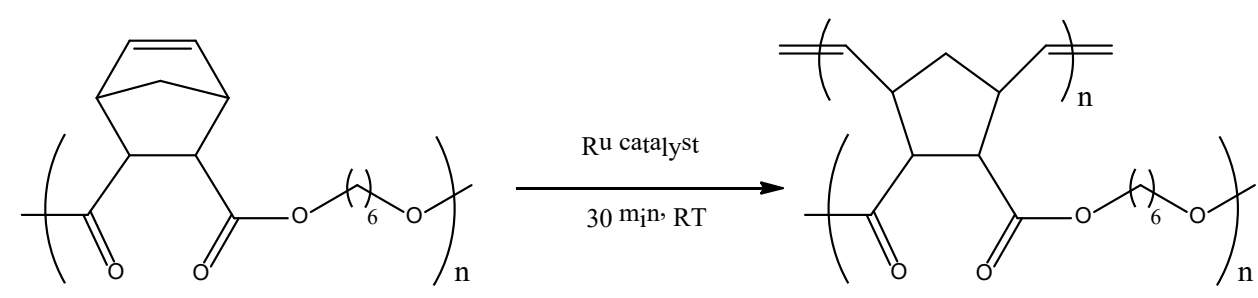

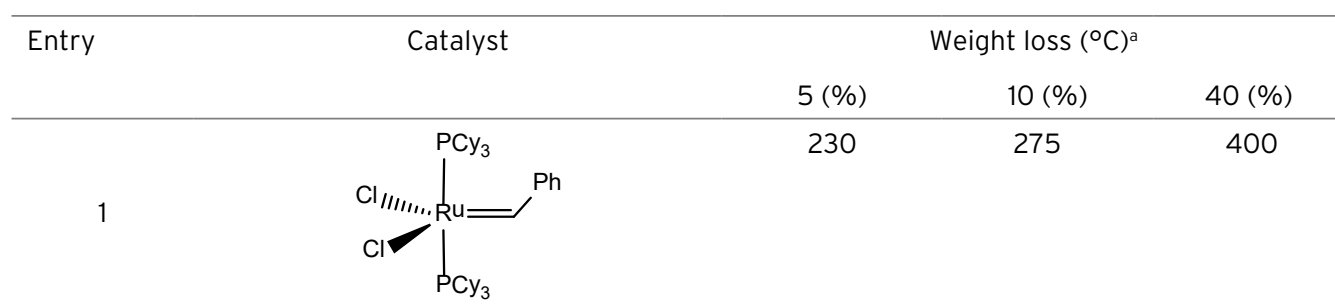

2

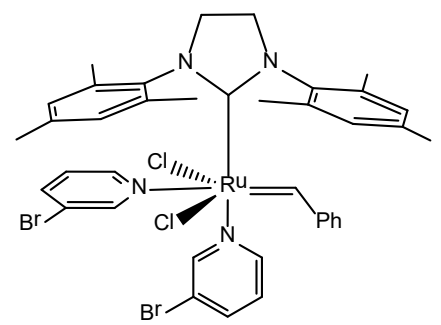

3

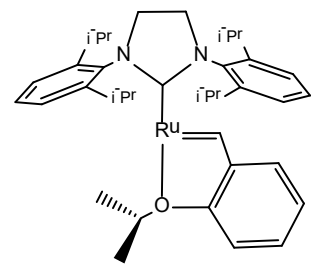


On the next trial, ring-opening metathesis reactions of $\mathrm{P} 1$ was carried out using Grubbs $1^{\text {st }}, 3^{\text {rd }}$, Hoveyda-Grubbss $2^{\text {nd }}$ generation catalysts to investigate the gelation behaviour of $\mathrm{P} 1$. It is well known in literature that highly strained norbornene ring can undergo ring opening metathesis reactions in the presence of Grubbs type ruthenium catalysts, forming oligomeric/polymeric vinly substituted cyclopentane rings. In the case of $\mathrm{P} 1$, which is a polyester derivative with repeating norbornene rings, norbornene group can undergo ring openingcross metathesis via inter-molecular or intra molecular pathways, resulting in a cross-linked polymeric material. The effect of cross-link on thermal stability of the polymers was investigated using TGA analysis. As it can be seen in Table 3, the 5,10 and $40 \%$ weight loss values shifted to higher temperature values, indicating the effect of crosslinking on overall structure of P1.

\section{CONCLUSION}

Unsaturated polyesters derived from polycondensation of 1,6-hexanediol and 5-norbornene-2,3-dicarboxylic anhydride were successfully modified via ring opening/cross metathesis reactions. It has shown that polymer properties ( $T_{g^{\prime}}$ solubility, polarity) can be tuned by integrating functional groups via cross metathesis. In addition, thermoplastic like materials were synthesized from unsaturated polyesters using Grubbs type ruthenium metathesis catalysts. The effect of cross-link, which was exerted by ring-opening metathesis polymerization of norbornene moiety was demonstrated by TGA analysis.

\section{References}

1. K.E. Uhrich, S.M. Cannizzaro, R.S. Langer, K.M. Shakesheff, Polymeric systems for controlled drug release, Chem. Rev., 99 (1999) 3181-3198.

2. G. Chen, T. Ushida, T. Tateishi, Scaffold design for tissue engineering Macromol. Biosci., 2 (2002) 67-77.

3. C.M. Agrawal, K.F. Haas, D.A. Leopold, H.G. Clark, Evaluation of poly(L-lactic acid) as a material for intravascular polymeric stents, Biomaterials, 13 (1992) 176-182.
4. A. Lendlein, R. Langer, Biodegradable, elastic shape-memory polymers for potential biomedical applications, Science, 296 (2002) 1673-1676.

5. F.B. Bujans, R. Martinez, M.Y.Y. Pedram, P. Ortiz, $H$. Frey, Water-soluble polyesters from long chain alkylesters of citric acid and poly(ethylene glycol), Eur. Polym. J., 43 (2007) 1288-1301.

6. J.F. Lutz, Sequence-controlled polymerizations: the next Holy Grail in polymer science, Polym. Chem., 1 (2010) 55-62.

7. Y. Tachibana, T. Masuda, M. Funabashi, M. Kunioka, Chemical synthesis of fully biomass-based poly(butylene succinate) from inedible-biomassbased furfural and evaluation of its biomass carbon ratio, Biomacromolecules, 11 (2010) 2760-2765.

8. B.G. Amsden, G. Misra, F. Gu, H.M. Younes, Synthesis and characterization of a photo-cross-linked biodegradable elastomer, Biomacromolecules, 5 (2004) 2479-2486.

9. Y. Wang, G.A. Ameer, B.J. Sheppard, R.A. Langer, Tough biodegradable elastomer, Nat. Biotechnol., 20 (2002) 602-606.

10. A.H. Brown, V.V. Sheares, Amorphous unsaturated aliphatic polyesters derived from dicarboxylic monomers synthesized by Diels-Alder chemistry, Macromolecules, 40 (2007) 4848-4853.

11. R. Baumgartner, Z. Song, Y. Zhang, J. Cheng, Functional polyesters derived from alternating copolymerization of norbornene anhydride and epoxides, Polymer Chemistry, 6 (2015) 3586-3590.

12. A.B. Cherian, B.T. Abraham, E.T. Thachil, Modification of unsaturated polyester resin by polyurethane prepolymers, J. App. Polym. Sci., 100 (2006) 449456.

13. C. Ai, G. Gong, X. Zhao, P. Liu, Determination of carboxyl content in carboxylated nitrile butadiene rubber (XNBR) after degradation via olefin cross metathesis, Polym. Test., 60 (2017) 250-252.

14. L. Fournier, C. Robert, S. Pourchet, A. Gonzales, L. Williams, J. Prunet, C.M. Thomas, Facile and efficient chemical functionalization of aliphatic polyesters by cross metathesis, Polym. Chem., 7 (2016) 3700-3704.

15. F. Sinclair, L. Chen, B.W. Greenland, M.P. Shaver, Installing multiple functional groups on biodegradable polyesters via post-polymerization olefin crossmetathesis, Macromolecules, 49 (2016) 6826-6834.

16. X. Michel, S. Fouquay, G. Michaud, F. Simon, J.M. Brusson, J.F. Carpentier, S.M. Guillaume, $\alpha, \omega^{-}$ Bis(trialkoxysilyl) difunctionalized polycyclooctenes from ruthenium-catalyzed chain-transfer ring-opening metathesis polymerization, Polym. Chem., 7 (2016) 4810-4823.

17. Y. Tachibana, M. Yamahata, K. Kasuya, Synthesis and characterization of a renewable polyester containing oxabicyclic dicarboxylate derived from furfural, Green Chem., 15 (2013) 1318-1325.

18. R.F. Fischer, Polyesters from epoxides and anhydrides, J. Polym. Sci. Part A: Polym. Chem., 44 (1960) 155-172. 